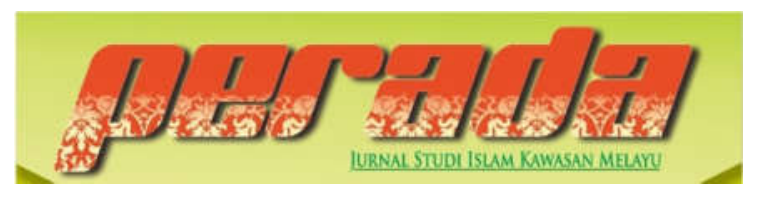

\author{
Perada: Jurnal Studi Islam Kawasan Melayu \\ ISSN 2656-7202 (P) ISSN 2655-6626 (0) \\ Volume 4 Nomor 2, Juli-Desember 2021 \\ DOI: https://doi.org/10.35961/perada.v4i2.383
}

\title{
GENEALOGIS MELAYU BUGIS: \\ KAJIAN HISTORIOGRAFI TERHADAP ASAL USUL UPU DAENG LIMA BERSAUDARA DALAM SUMBER-SUMBER MELAYU
}

\author{
Syahrul Rahmat \\ STAIN Sultan Abdurrahman Kepulauan Raiu \\ Syahrul28@gmail.com
}

\begin{abstract}
ABSTRAK
Upu Daeng lima Bersaudara berikut keturunannya tercatat memiliki pengaruh luar biasa di Kerajaan Riau Lingga. Mereka adalah anak Daeng Rilakka yang merupakan keturunan dari La Maddusila, seorang Raja Luwu di tanah Bugis. Silsilah atau ranji keturunan mereka disebut dalam sejumlah sumber, termasuk sumber-sumber Melayu. Setidaknya terdapat dua sumber Melayu yang bercerita tentang asal usul mereka, yaitu naskah Tuhfat Al-Nafis dan Silsilah Melayu Bugis yang ditulis pada abad ke-19 oleh Raja Ali Haji. Pada artikel ini terdapat dua isu penting, pertama adalah menganalisa silsilah Upu Daeng Lima Bersaudara dari kedua sumber, serta kedua menganalisa penulisan silsilah tersebut dari sudut pandang historiografi. Rangkaian penelitian ini menggunakan metode penelitian sejarah yang dimulai dari heuristik, verifikasi sumber, iintreprestasi dan historiografi. Secara umum, Tuhfat Al-Nafis dan Silsilah Melayu Bugis sudah mulai ditulis dengan menggunakan metode penulisan sejarah, hanya saja hal tersebut belum diterapkan secara konsisten untuk seluruh narasi, terutama terkait silsilah. Sekalipun demikian, perbedaan jumlah nama dalam silsilah pada kedua kitab itu mengindikasikan Raja Ali Haji dalam Tuhfat al-Nafis mulai menerapkan verifikasi terhadap sumber yang digunakan.
\end{abstract}

Upu Daeng Lima Bersaudara and their descendants were noted to have an extraordinary influence in the Riau Lingga Kingdom. They are the children of Daeng Rilakka who is a descendant of La Maddusila, a King of Luwu in the land of Bugis. Their genealogy is mentioned in some of Malay sources. There are at least two Malay sources telling about their origins that are the Tuhfat Al-Nafis and the Silsilah Melayu Bugis manuscripts written in the 19th century by Raja Ali Haji. In this article, there are two important issues. The first is to analyze the genealogy of Upu Daeng Lima Bersaudara from both sources and the second is to analyze the writing of the genealogy from a historiographical perspective. The historical research method was used in this research starting from heuristic, source verification, interpretation and historiography. In general, Tuhfat Al-Nafis and Silsilah Melayu Bugis have been written by using the historical writing method, but the method itself 
has not been applied consistently for all narration, especially those related to genealogy. However, the difference in the number of names in the genealogy of the two books indicated that Raja Ali Haji in Tuhfat al-Nafis began to verify to the sources used.

Keywords: historiography, genealogy, Malay-Bugis, Raja Ali Haji, Tuhfat Al-Nafis. 


\section{PENDAHULUAN}

Sejarah etnis Bugis di kawasan Melayu, terutama di Kepulauan Riau tidak terlepas dari sosok Daeng Rilakka bersama kelima anaknya yang dikenal dengan sebutan Upu Daeng Lima Bersaudara. Sekalipun bukan gelombang migrasi pertama, akan tetapi keberadaan mereka di kawasan Melayu sangat berpengaruh. Kiprah keturunan mereka dalam Kerajaan Riau Lingga mengisi dinamika internal maupun eksternal kerajaan. ${ }^{1}$

Kelima anak Daeng Rilakka tersebut adalah Daeng Perani, Daeng Menambun, Daeng Marewah, Daeng Celak dan Daeng Kemasi. Setelah melanglang buana di kawasan Kepulauan Melayu hingga ke Kamboja, kelima Daeng ini akhirnya terlibat dalam konflik internal Kerajaan Johor yang di kemudian hari menjadi Kerajaan Riau Lingga. ${ }^{2}$ Sekalipun terlibat dalam konflik antara Tengku Sulaiman dengan Raja Kecik dalam memperebutkan kekuasaan, pada akhirnya hanya dua nama yang benar-benar berkiprah dalam perpolitikan kerajaan. Dua nama tersebut adalah Daeng Marewah yang menjabat sebagai Yang Dipertuan Muda (YDM) Riau I dan Daeng Celak sebagai YDM Riau II. ${ }^{3}$ Hingga masa-masa setelahnya, kiprah keturunan Bugis di Kerajaan Riau Lingga didominasi oleh keturunan Daeng Celak.

Sejumlah sumber lokal menyebutkan bahwa Daeng Rilakka berikut anakanaknya merupakan keturunan bangsawan Luwu yang bermigrasi ke daerah barat atau kawasan Melayu. Migrasi tersebut dapat ditemui pada sejumlah sumber lokal, terutama sumber-sumber yang ditulis orang-orang Melayu, baik itu keturunannya

${ }^{1}$ Syahrul Rahmat, Bugis di Kerajaan Melayu: Ekesistensi Orang Bugis dalam Pemerintahan Kerajaan Johor-Pabang-Riau-Lingga', Perada, 2.1 (2019), h. 3544

${ }^{2}$ Faisal Sofyan, Sejarah Persemendaan Melayu dan Bugis, (Tanjung Pinang: Milaz Grafika, 2013), h. 59

3 Ahmad Dahlan, Sejarah Melayu (Jakarta: Kepustakaan Populer Gramedia, 2014), h. 201-203 atau tidak. Riwayat perjalan Upu Daeng Lima bersaudara bersama ayahnya cukup jelas disebutkan dalam dua sumber Melayu, yaitu Tuhfat Al Nafis (lebih lanjut ditulis TN) serta Silsilah Melayu Bugis (lebih lanjut ditulis SMB) yang ditulis oleh Raja Ali Haji.

Lebih lanjut artikel ini mengulas tentang penulisan silsilah Upu Daeng Lima Bersaudara di dalam sumber lokal dengan perspektif historiografi. Dua sumber yang disebutkan sebelumnya merupakan rujukan utama bagi sejumlah peneliti sejarah ketika meneliti sejarah berkaitan dengan Kerajaan Riau Lingga maupun keturunan Bugis di kawasan Melayu. Keberadaan sumber lokal ini merupakan hal penting untuk mendapatkan sudut pandang yang seimbang dengan tidak hanya mengacu pada perspektif asing, akan tetapi juga perspektif lokal.

Terlepas dari adanya kecenderungan keberpihakan, atau pun dominasi narasi lokalitas pada sumber yang dimaksud, pada dasarnya tulisan ini bertujuan untuk melihat pola penulisan sejarah yang dilakukan pada abad ke-19 oleh masyarakat lokal. Hadirnya sumber lokal ini menjadi bagian dari khazanah intelektual di masa lalu. Pasalnya, tidak banyak penulis-penulis di masa itu yang mencoba untuk menuliskan sejarahnya sendiri, sehingga sebagian besar naskah atau pun manuskrip di Nusantara lebih didominasi oleh manuskrip keagamaan.

Agar lebih spesifik, penulisan artikel ini dikerucutkan pada dua permasalahan. Pertama adalah mengidentifikasi silsilah Upu Daeng Lima Bersaudara di dalam naskah TN dan SMB yang ditulis pada abad ke-19. Kedua adalah untuk menganalisa hasil identifikasi silsilah Upu Daeng Lima Bersaudara dari perspektif historiografi.

Kajian terkait judul yang diajukan belum banyak dilakukan. Salah satu kajian yang menyinggung aspek historiografi dilakukan oleh Alimuddin Hasan pada tahun 2009. Dalam artikel berjudul 
Historiografi Melayu: Kajian Atas Tubfat alNafs Karya Raja Ali Haji itu, Hasan menyebutkan bahwa TN merupakan karya sejarah yang cukup canggih dibanding karya yang serupa sebelum abad ke-20. ${ }^{4}$ Artikel lain ditulis oleh Muhammad Bahar Akkase Teng dengan judul tulisan Tubfat Al-Nafis: Karya Sastra Sejarah (Melayu) Dalam Perspektif Sejarah. Pada artikel yang ditulis pada tahun 2015 ini, Teng mengulas TN sebagai sebuah karya sastra yang di dalamnya memuat latar sejarah ${ }^{5}$.

Penelusuran genologis keturunan Bugis di Melayu sebelumnya juga sudah dilakukan oleh J. Noorduyn pada tahun 1988. Pada artikel yang diterbitkan oleh Journal of the Malaysian Branch of the Royal Asiatic Society dengan judul The Bugis Genealogy of the Raja Muda Family of Riau-Johor tersebut, Noorduyn mengkaji silsilah Melayu-Bugis yang ada di Riau dengan merujuk pada Manuskrip TN. ${ }^{6}$ Sekilas penelitian yang dilakukan Noorduyn hampir serupa dengan penelitian yang penulis lakukan, akan tetapi penelitian ini sama sekali berbeda. Noorduyn fokus untuk menganalisis nama-nama dalam silsilah pada kedua manuskrip tersebut. Sementara penelitian ini membahas silsilah yang terdapat dalam TN dan SMB yang sudah ditransliterasi, selain itu penelitian ini diarahkan pada identifikasi historiografi yang dilakukan pada abad ke-19.

Selain tiga di atas, kajian yang cukup terkenal terkait TN adalah kajian yang dilakukan oleh Virginia Matheson Hooker, sebuah kajian filologi dengan melakukan transliterasi dan transkipsi terhadap kitab TN. Kajian Hooker ini cukup memberikan

4 Alimuddin Hasan, 'Historiografi Melayu: Kajian Atas Tubfat al-Nafs Karya Raja Ali Haji', AlFikera: Jurnal Ilmiah Keislaman, 8. 2 (2009)

${ }^{5}$ Muhammad Bahar Akkase Teng, Tubfat Al -Nafis: Karya Sastra Sejarah (Melayu) Dalam Perspektif Sejarah', Paramasastra, 2.1 (2015)

${ }^{6} \mathrm{~J}$. Noorduyn, 'The Bugis Genealogy of the Raja Muda Family of Riau-Johor', Journal of the Malaysian Branch of the Royal Asiatic Society, 61. 2 (1988), h. 63-92 banyak kontribusi terhadap para peneliti sejarah, sebab tidak perlu lagi merujuk naskah asli, telaah yang dilakukannya dianggap sudah layak sebagai referensi. Dari sejumlah kajian di atas, karya kedua (Silsilah Melayu Bugis) yang menjadi objek penelitian ini kajiannya tidak sebanyak TN. Keberadaannya hanya disinggung memiliki hubungan dengan TN. Salah satu kajian terhadap naskah SMB sebelumnya dilakukan oleh Hans Overbeck pada artikel berjudul Silsilah Melayu dan Bugis dan Sekalian Raja-raja-nya yang dipublikasikan pada tahun $1926 .^{7}$

\section{METODE PENELITIAN}

Penulisan artikel ini berangkat dari rangkaian penelitian sejarah. Terdapat empat tahapan yang harus dilalui untuk sampai pada hasil, hal itu dimulai dari heuristik, kritik sumber, intreprestasi dan historiografi. ${ }^{8}$ Langkah heuristik pada penelitian ini dilakukan dengan mengumpulkan sumber utama dalam kajian ini, yaitu kitab TN dan kitab SMB. Kedua kitab yang digunakan merupakan hasil transkipsi dan transliterasi yang sudah dilakukan oleh peneliti sebelumnya. Selain dua kitab itu, penulis juga mengumpulkan sumber lain yang sezaman atau memiliki tema yang yang sama dengan objek penelitian. Sumber tersebut berupa buku maupun artikel jurnal.

Setelah melewati tahap heuristik, selanjutkan dilakukan kritik terhadap sumber-sumber yang dikumpulkan. Hal ini dilakukan dengan mengumpulkan informasi yang dibutuhkan, kritik dilakukan terhadap unsur eksternal yang berkaitan dengan fisik sumber berikut penulisnya, serta unsur internal yang lebih kepada kritik teks. Lepas dari kritik,

\footnotetext{
${ }^{7}$ Hans Overbeck, Silsilah Melayu Bugis dan Raja-rajanya', Journal of the Malayan Branch of the Royal Asiatic Society, 4.3 (1926), h. 339-381

8 Abd Rahman Hamid dan Muhammad Saleh Madjid, Pengantar Ilmu Sejarah (Yogyakarta: Ombak, 2015), h. 43-51.
} 
selanjutnya masuk ke tahapan intreprestasi, informasi-informasi yang terkumpul selanjutnya diolah dan dianalisa. Analisa dilakukan untuk menyesuaikan kebutuhan informasi guna menyusun narasi terkait tema kajian. Tahap akhir dari seluruh rangkaian ini adalah historiografi, yaitu penulisan sejarah.

Analisa terhadap dua karya yang hadir pada abad ke-19 tersebut dianalisa dengan pendekatan historiografi. Menggunakan pendekatan ini, kajian diarahkan pada konten atau teks yang ditulis oleh seorang penulis sejarah. Pada teks yang ditulis oleh seorang penulis sejarah dapat dilacak persepsi, intreprestasi serta metode yang dipergunakan dalam penulisan. ${ }^{9}$ Selain itu, beberapa hal yang juga perlu dilihat pada penelitian ini adalah latar belakang penulis, wawasan, serta aluran penulisan yang dipergunakan. ${ }^{10}$

Carl Becker (1938) menyebutkan, sederhanya historiografi berkaitan dengan pencatatan karya sejarah klasik dengan beberapa standar, seperti sudut pandang penulis, akurasi, serta keterbacaan karya tersebut, hal ini kemudian dinilai dengan tolak ukur standar modern. Pada tingkatan ini, historiografi memberikan informasi tentang sebuah peristiwa sejarah berikut sejarawannya. Pengetahuan terkait sejarah yang sudah terverifikasi itu memberikan kontribusi nilai untuk pengetahuan. ${ }^{11}$

Sebuah karya sejarah, di dalamnya tidak hanya akan termuat informasiinformasi terkait sebuah peristiwa di masa lalu. Di dalamya juga akan diulas siapa penulis peristiwa tersebut. Dalam tahap penulisan sejarah, hal ini berkaitan dengan kritik sumber dalam penulisan karya tersebut. Dalam penelitian sejarah, tahap

${ }^{9}$ Mestika Zed, Pengantar Studi Historiografi, (Padang: Proyek Peningkatan Pengembangan PT. Universitas Andalas, 1984), h. 7

10 Lukmanul Hakim, 'Historiografi Modern Indonesia: Dari Sejarah Lama Menuju Sejarah Baru", Khazanah: Jurnal Sejarah dan Kebudayaan Islam, 8. 16 (2018), h. 69-82

11 Carl Becker, What is Historiography?', American Historical Review, 44. 1 (1938), h. 20-28. ini tergolong dalam kritik eksternal, dimana di dalamnya terdapat beberapa hal yang harus ditinjau seperti kapan sebuah karya ditulis, dimana tempat karya itu ditulis, apa media yang digunakan untuk menulis serta siapa yang menulis karya tersebut. ${ }^{12}$

Sebuah tulisan sejarah idealnya adalah sebuah karya akademis yang sifatnya ilmiah. Hal ini berkaitan dengan upaya yang dilakukan oleh seorang sejarawan dalam menggunakan metode penelitian sejarah. Sekalipun demikian, historiografi memiliki fase perkembangannya sendiri untuk kemudian sampai pada tatanan penulisan sejarah kritis.

Tugas dari seorang sejarawan historiografi sederhanya dapat digambarkan dengan usaha untuk melacak refleksi kehidupan di masa lalu. Hal itu kemudian dianalisa apakah telah memberikan informasi terkait kontiniutas dari masa lalu, sekarang dan masa mendatang. Pandangan Ernst Breisach, dalam perkembangan historiografi, seorang sejarawan historiografi diibaratkan menyortir gandum dari sekam. Mereka memberikan preferensi terhadap sejarawan lain yang kemudian mengarahkan historiografi untuk memiliki tujuan yang jelas dan terarah. ${ }^{13}$

\section{KITAB TUHFAT AL-NAFIS DAN SILSILAH MELAYU BUGIS.}

Tuhfat Al-Nafis adalah kitab yang lekat dengan tokoh Raja Ali Haji, seorang pujangga kerajaan yang hidup pada masa Kerajaan Riau Lingga. Kiprahnya dalam literasi sudah tidak diragukan lagi, ia tercatat sudah menulis sejumlah karangan yang banyak dijadikan kajian oleh para peneliti pada masa sekarang. Selain karangan berupa syair, gurindam atau pun

12 Abd Rahman Hamid dan Muhammad Saleh Madjid, Pengantar Ilmu Sejarah, h. 48.

13 Ernst Breisach, Historiography: Ancient, Medieval and Modern (Chicago: The University of Chicago Press, 1994), h. 4. 
bahasa, ia juga menulis karangan yang berisi narasi-narasi sejarah.

Raja Ali Haji merupakan keturunan dari bangsawan Bugis yang menjadi topik pembahasan dalam artikel ini. Silsilah Raja Ali Haji sampai pada Daeng Rilakka. Ia merupakan anak dari Raja Ahmad bin Raja Haji Fisabilillah (YDM Riau IV) bin Daeng Celak (YDM Riau II) bin Daeng Rilakka. Sekalipun tidak menjabat sebagai Yang Dipertuan Muda, akan tetapi Raja Ali Haji dan ayahnya Raja Ahmad dikenal sebagai cendikiawan yang melahirkan banyak karya.

Naskah TN pada dasarnya sudah diteliti oleh Virginia Matheson Hooker pada 1982. Kajian tersebut merupakan penelitian filologi yang mengulas TN dari segi kodikologi filologi. Selain menyajikan transliterasi, Hooker juga menyajikan transkipsi. Tidak hanya itu, pada bagian awal penelitiannya, ia juga menyajikan kajian terhadap manuskrip yang diteliti, termasuk di dalamnya identifikasi sebaran manuskrip, berikut penulisnya.

TN adalah naskah yang ditulis pada abad ke-19. Manuskrip ini sebenarnya tidak mengacu pada nama Raja Ali Haji semata, akan tetapi juga mengacu pada nama Raja Ahmad. Manuskrip TN punya dua versi, yaitu versi panjang dan versi pendek. Selisih waktu penulisan kedua versi tersebut juga tidak terlalu jauh. Versi pendek mulai ditulis pada tahun 1865 dan versi panjang ditulis pada 1866. Berangkat dari kedua versi itu, besar kemungkinan bahwa versi pendek TN ditulis oleh Raja Ahmad dan kemudian disempurnakan dalam versi panjang oleh Raja Ali Haji pada $1866 .^{14}$

Pelacakan terhadap naskah TN berujung pada penemuan 6 buah naskah, yang terdiri dari satu naskah versi pendek kepunyaan Arend Ludolf van Hasselt (Residen Riau 1893). Lima lainnya adalah

14 Virginia Matheson Hooker, Tufhat AlNafis, Sejarah Melayu Islam, trans. by Ahmad Fauzi Basri (Kuala Lumpur: Dewan Bahasa dan Pustaka Kementrian Pendidikan Malaysia, 1991), h. 45 naskah versi panjang. Naskah pertama dimiliki oleh W.E. Maxwell (Residen Selangor 1889-1892). Naskah kedua dimiliki oleh Tengku Fatimah, anak Sultan Abu Bakar, Johor, naskah ini kemudian dipinjam oleh Richard Winstedt saat menjabat Penasehat Umum Kerajaan Johor tahun 1931. Naskah ketiga dimiliki oleh Raja Aziz bin Raja Kasim. Naskah keempat kepunyaan A. Ringkes (ketua Balai Pustaka tahun 1917-1927), naskah ini merupakan koleksi Perpustakaan Universitas Leiden. Terakhir adalah naskah yang ditemukan Y.M Tengku Ismail bin Tengku Su, Terengganu. ${ }^{15}$

Hingga masa sekarang, TN kerap dijadikan referensi oleh para peneliti yang ingin meneliti sejarah Melayu, terutama berkaitan dengan Kerajaan Johor Pahang Riau Lingga. Sebagian teks yang tertulis di dalam TN merupakan peristiwa-peristiwa yang terjadi pada masa ia hidup, dengan kata lain ia merupakan saksi sejarah dari masa tersebut. Sementara sebagian teks lainnya berisi peristiwa-peristiwa yang terjadi sebelum ia lahir, baik itu hanya berjarak belasan dan puluhan tahun, hingga ratusan tahun sebelumnya.

Di dalam TN, silsilah Upu Daeng Lima Bersaudara ditulis pada bagian awal karangan. Silsilah tersebut ditulis secara naratif. Pada karangan ini setidaknya terdapat 36 nama yang dimulai dari Daeng Rilakka hingga Sitti Mallangkik yang berada di puncak silsilah. ${ }^{16}$

Sementara Silsilah Melayu Bugis adalah karangan lain yang juga memuat informasi terkait sejarah para keturunan bangsawan Bugis di kawasan Melayu. Sebagaimana TN, naskah SMB yang digunakan dalam penelitian adalah hasil transliterasi dan transkripsi yang dilakukan oleh Evawarni dan Sindu Gazalba pada tahun 1993/1994. Berbeda dengan

${ }^{15}$ Alimuddin Hasan, 'Historiografi Melayu: Kajian Atas Tubfat al-Nafs Karya Raja Ali Haji', h. 400-403

16 Virginia Matheson Hooker, Tufhat AlNafis, Sejarah Melayu Islam., h. 151 
Virginia Matheson yang mengulas TN secara mendalam, kajian yang dilakukan oleh Evawarni hanya sebatas transkipsi dan transliterasi, serta tidak menggunakan metode filologi maupun kodikologi.

Naskah SMB disalin oleh Haji Abdullah bin Khairuddin pada 27 Sya'ban 1282 Hijriah atau bertepatan dengan 14 Januari 1866 Masehi. ${ }^{17}$ Informasi tersebut ditemukan pada bagian akhir naskah atau kolofon. Hanya saja bagian ini tidak memuat informasi dimana naskah ini ditulis.

Penelusuran berikut pengkajian terhadap naskah SMB juga sudah dilakukan oleh sejumlah peneliti, seperti Ted Beardow (1986), Moh Yusuf Noor (1980) dan bahkan Virginia Matheson juga pernah mengkajinya pada tahun 1973. Sementara teks Johor yang sudah dicetak ulang juga pernah dialihaksarakan oleh Arenawati pada $1973 .{ }^{18}$ Selain itu, pada tahun 1926, transliterasi naskah SMB juga sudah dilakukan oleh Hans Overbeck. Naskah tersebut ditemukannya di Singapura yang dicetak pada tahun $1900 .{ }^{19}$

Naskah SMB yang penulis gunakan dalam penelitian ini sama sekali tidak memuat informasi tentang pengarang. Pada bagian mukadimah naskah hanya disebutkan bahwa tulisan tersebut disuratkan oleh Haji Abdullah bin Khairudin. Oleh Hooker, naskah ini juga disebut sebagai naskah SMB tertua yang pernah ditemukannya. Naskah tersebut mulai ditulis pada 29 Agustus 1865 dan selesai pada Januari $1866 .{ }^{20}$ Sebagian besar pendapat menyebutkan bahwa naskah ini ditulis oleh Raja Ali Haji. ${ }^{21}$

${ }^{17}$ Haji Abdullah, Silsilah Melayu Bugis, terj. Evawarni dan Sindu Galba, (Tanjungpinang: Balai Kajian Sejarah dan Nilai Tradisional, 1993), h. 366

${ }^{18}$ Virginia Matheson Hooker, Tufhat Al-

Nafis, Sejarah Melayu Islam., h. 31 Raja-rajanya'

${ }^{19}$ Hans Overbeck, 'Silsilah Melayu Bugis dan

${ }^{20}$ Virginia Matheson Hooker, Tufhat AlNafis, Sejarah Melayu Islam., h. 30

${ }^{21}$ Hans Overbeck, 'Silsilah Melayu Bugis dan Raja-rajanya', Ibid. Lihat juga Virginia Matheson
HISTORIOGRAFI SILSILAH UPU DAENG LIMA BERSAUDARA DALAM TUHFAT AL-NAFIS DAN SILSILAH MELAYU BUGIS

Silsilah dalam Tuhfat Al-Nafis dan Silsilah Melayu Bugis

Naskah Tuhfat Al-Nafis dan Silsilah Melayu Bugis sama-sama memuat informasi tentang asal-usul Upu Daeng Lima Bersaudara. Jika TN punya 36 nama di atas Daeng Lima Bersaudara, maka pada naskah SMB memiliki jumlah berbeda, yaitu 39 nama. Penghitungan tersebut dimulai dari nama Daeng Rilakka yang merupakan ayah mereka, hingga Sitti Mallangkik yang berada di puncak silsilah (lihat tabel 1).

Perbedaan ini terdapat pada beberapa nama dalam urutan yang berbeda. Dalam TN, urutan ke-16 terdapat nama La Pannyiwi Mallopi ri Alak, sementara dalam SMB pada urutan ke-16 terdapat nama Lupah Bayu Malupi Riyalaah. Nama-nama tersebut kembali singkron pada urutan ke 17 (dalam TN) dan urutan ke-18 (dalam SMB), yaitu pada nama Sessung Riwuk Nannuk ri Peretiwi. Sementara urutan ke-17 dalam SMB terdapat nama Lupah Dulang Maljangi Rurallangi, nama ini sama sekali tidak ditemukan di dalam $\mathrm{TN}^{22}$

Hooker, Tufbat Al-Nafis, Sejarah Melayu Islam., h. 33, 57,61 .

22 Secara huruf, terdapat perbedaan penyebutan antara satu nama dalam TN dan SMB. Jika ditelaah, pada dasarnya itu adalah nama yang sama, perbedaan itu berangkat dari pemahaman penterjemah (pemahaman konteks dan referensi tambahan), karena kedua naskah ini asalnya ditulis dalam aksara Jawi atau Arab Melayu. Hal tersebut memiliki pengaruh yang besar dalam penerjemahan. Sebagai contoh, dalam TN yang dialihaksarakan oleh Virginia Matheson Hooker, ditulis nama La Pannyiwi Mallopi ri Alak, sementara dalam SMB yang dialihaksarakan oleh Evawarni ditulis nama Lupah Bayu Malupi Riyalaah. Secara bunyi, kata Mallopi memiliki bunyi yang hampir sama dengan Malupi. Ri Alak diperkirakan Riyalaah dalam SMB. Dalam tulisan 
Selanjutnya perbedaan urutan juga terjadi pada nama La Sessung Riwuk Matindro ri Larompong yang dalam TN berada pada urutan ke-20 (lihat table 1 nomor 20). Setelah nama ini, urutan dalam TN langsung pada nama To Allaik Matindro ri Tanatekko. Sementara itu dalam SMB, setelah nama La Sessung Riwuk Matindro ri Larompong terdapat nama lain, yaitu Tuka Madang Mutanru Ranpa. Setelahnya baru diikuti oleh nama To Allaik Matindro ri Tanatekko. ${ }^{23}$

Perbedaan ketika terdapat pada nama Mappaseking Matindro ri Kannana (dalam TN berada pada urutan ke 32), setelahnya diikuti oleh nama La Tendriupak. Sejajar dengan nama ini (lihat table 1 nomor 32), dalam SMB tertulis nama Mappasilang Mutandaru Rasalakun dan diikuti oleh nama Latuwandak Mutandaru Raknan. Setelah dua nama ini baru masuk pada nama La Tendriupak/Latundari Jupa. ${ }^{24}$

\section{Penulisan Sejarah Silsilah dalam Tuhfat Al-Nafis dan Silsilah Melayu Bugis.}

Sebagaimana disebutkan di awal, TN dan SMB adalah dua naskah yang ditulis pada masa yang sama, yakni abad ke-19. Selain itu, penulis kedua naskah ini juga dilakukan oleh orang yang

ini, penulis lebih cenderung pada transliterasi Hooker dibanding Evawarni. Sebab, dalam bukunya, Hooker menyebutkan pedoman transliterasi berikut pertanggungjawaban edisi, selain itu ia juga merujuk beberapa sumber pendukung untuk memudahkannya dalam transliterasi, sementara hal tersebut tidak ditemukan dalam transliterasi SMB.

23 Dalam transliterasi SMB, nama La Sessung Riwuk Matindro ri Larompong ditulis Sasung Ruwak Mutandaru Larapung. Nama To Allaik Matindro ri Tanatekko ditulis Tulayak Mutandru Rotan Tuku.

24 Mappaseking dalam TN diperkirakan ditulis Mapasilang dalam SMB. Matindro dalam TN diperkirakan ditulis Mutandaru dalam SMB. Sementara Kannana dalam TN diperkirakan ditulis Raknan dalam SMB. sama, yakni Raja Ali Haji. Bahkan kedua naskah ini ditulis dalam rentang waktu yang sangat berdekatan.

Naskah TN yang terdiri dari dua versi ditulis dalam masa 1865 hingga 1866. Penyusunan TN versi pendek sudah dimulai sejak 23 Desember 1865 yang dilakukan oleh Raja Ahmad. Penyempurnaan TN dalam bentuk panjang dilakukan oleh Raja Ali Haji yang ditulis pada 1866. Oleh karenanya, penyusunan SMB dilakukan pada waktu yang hampir bersamaan oleh Raja Ali Haji dengan penyusunan TN oleh ayahnya. ${ }^{25}$

Penulisan silsilah pada naskah SMB merujuk pada sebuah kitab yang didapatkan dari Said Syarif Abdurrahman bin Said Syarif Qasim Sultan Pontianak bin Said Syarif Abdurrahman Al-Qudri. ${ }^{26}$ Kitab yang menjadi rujukan itu disebutkan bahwa sebagian besar raja-raja mereka (Pontianak) berasal dari Bugis. Penulisan naskah yang kemudian dikenal dengan Silsilah Melayu Bugis ini dilakukan setelah mendapatkan sumber dari Said Syarif Abdurrahman, yang bertujuan untuk memberikan informasi terkait silsilah agar diketahui oleh keturunannya kelak. Selain itu, Ted Beurdow menyebut SMB yang dikarang oleh Raja Ali Haji juga menggunakan sejumlah sumber-sumber tertentu. ${ }^{27}$

Sementara itu, TN juga menggunakan lebih dari satu referensi dalam penulisan. Kitab-kitab yang menjadi rujukan itu merupakan kitabkitab yang berisi narasi tentang kawasan Melayu. Di dalam TN pun penulis sudah mulai memilih bagian-bagian yang dinilai layak untuk dikutip.

Sejumlah kitab yang menjadi rujukan dalam TN adalah Siarah Siak,

${ }^{25}$ Virginia Matheson Hooker, Tufhat AlNafis, Sejarab Melayu Islam., h. 29-30, 57

${ }^{26}$ Haji Abdullah, Silsilah Melayu Bugis, h. 6

${ }^{27}$ Virginia Matheson Hooker, Tufhat Al-

Nafis, Sejarah Melayu Islam., h. 63 
Siarah Selangor, Siarah Pontianak dan Siarah Pihak Riau atau Siarah Karangan Engku Busu. Merujuk pada penelitian sejarah, pengarang TN juga mulai melakukan kritik terhadap teks yang akan dikutip, walaupun ada beberapa bagian yang terkesan diabaikan. Salah satu bentuk abai itu dengan adanya narasi "Demikianlah khabar orang tua-tua entabkan apa artinya wallabu'alam yang mana aku dengar dan aku libat di dalam siarah aku suratkan". 28

Teks pada TN dan SMB juga tidak terlepas dari unsur fiktif. Hal tersebut dapat ditemukan pada bagian awal silsilah, tepatnya pada bagian asal usul Sitti Mallangkik. Pada TN ditulis bahwa orang Bugis merupakkan keturunan dari Puteri Balqis yang berasal dari Yaman, seorang anak raja jin yang menjadi isteri Nabi Sulaiman. Puteri Balqis dengan Nabi Sulaiman memiliki anak laki-laki dan perempuan yang keturunan-keturunannya sampai ke tanah Bugis. ${ }^{29}$

Sementara di dalam SMB hal ini ditulis:

"Bermula adalah silsilah yang keturunan dari pada Bugis itu yaitu asalnya seorang raja perempuan di Negeri Luwnk. Kata setengah rawi keturunan daripada Balqis konon, 30

Pada sejumlah karya sastra sejarah, keterlibatan unsur mitos dan cerita fiktif kerap mengawali sebuah narasi historis. ${ }^{31}$ Sejumlah sumbersumber lokal yang sifatnya hikayat sebagian besar memuat unsur tersebut.

\footnotetext{
${ }^{28}$ Virginia Matheson Hooker, Tufhat Al-

Nafis, Sejarab Melayu Islam., h. 64-70

29 Virginia Matheson Hooker, Tufhat Al-

Nafis, Sejarah Melayu Islam., h. 150

${ }^{30}$ Haji Abdullah, Silsilah Melayu Bugis, h. 7

${ }^{31}$ Menurut Roolvink, sastra sejarah terdiri dari dua bagian, pertama memuat mitos dan legenda yang berisi asal-usul raja pada sebuah negeri, sementara bagian kedua adalah narasi sejarah. Liaw Yock Fang, Sejarah Kesusasteraan melayu Klasik (Singapura: Pustaka Nasional, 1982), h. 203
}

Hal itu kerap ditemukan pada genologis raja-raja yang dikaitkan dengan nabi. Oleh karenanya, salah satu karakteristik historiografi tradisional berupa sastra sejarah akan memuat unsur historis yang empiris dan juga fiksi. ${ }^{32}$

Karakter ini mengarah pada ciri sejarah konvensional yang hanya bercerita tentang peristiwa beserta prosesnya. Dalam hal ini mengapa dan bagaimana sebuah peristiwa terjadi tidak dijelaskan. Dalam penulisan sejarah modern, penulisan sejarah naratif dinilai tidak cukup, karena hanya memberikan jawaban terhadap pertanyaan yang sifatnya elementer. Sementara pertanyaan lebih lanjut yang sifatnya lebih kritis tidak terjawab. ${ }^{33}$

Sekalipun demikian, Raja Ali Haji sudah mulai melakukan kritik atau verifikasi terhadap narasi yang akan ia tulis, walaupun belum dilakukan secara maksimal. Merujuk Kuntowijoyo (2013), Raja Ali Haji baru melakukan verifikasi kredibilitas atas sumber, yaitu dengan mengulas apakah sumber yang digunakan bisa dipercaya atau tidak. Sementara untuk hal autentisitas sumber agaknya masih belum dilakukan maksimal dalam penulisan silsilah. ${ }^{34}$

Verifikasi kredibilitas atau biasa disebut dengan kritik internal terhadap sumber yang dilakukan Raja Ali Haji adalah berkaitan dengan narasi asal usul nenek moyang Orang Bugis. Sejumlah riwayat yang ia kutip menyebut bahwa mereka merupakan keturunan Ratu Balqis dan Nabi Sulaiman. Keturunanketurunan itulah yang kelak akan menjadi nenek moyang Orang Bugis.

Dalam naskah TN ia menulis:

${ }^{32} \mathrm{Mu}$ 'jizah, 'Historiografi Tradisional Raja-raja Melayu dan Kekuasaan dalam Hikayat Negeri Johor', Atavisme, 21.1 (2018), h. 17-34

33 Suhartono W. Paranoto, Teori \& Metodologi Sejarah (Yogyakarta: Graha Ilmu, 2014), h. $9-10$

34 Kuntowijoyo, Pengantar Imu Sejarah (Yogyakarta: Tiara Wacana, 2013), h. 77 
"Dalam pada itu Allah Subhanabu Wataala yang lebih tabu akan hakikat alumur kulliha, karena Balkis itu di negeri Saba pibak negeri tanah Yamani, anak raja jin jadi isteri nabi Allab Sulaiman 'alaibi alsallam. Maka berjaub-jauban benarlah Orang Bugis, entabkan sabkah, entabkan tidak, kaul perkataan setengah Orang Bugis itu, entabkan tidak, Allab Subbanabu Wata'ala yang lebih tabu. ${ }^{\prime 35}$

Sementara dalam naskah SMB ia menulis:

"Yakni Allab SWT yang terlebih mengetabui akan sebenar-benarnya entabkan betulkan seperti akuan orang-orang Bugis itu entabkan tidak karena tiada aku dapat dalam kitab-kitab tarekh yang Balqis itu pibak sebelah Bugis hanyalah Balqis pibak. sebelah Yaman dan ..................", "Kesimpulan di dalam itupun tiada boleh pula kita putuskan tidaknya karena pekerjaan itu harus kepada akal beleh juga anak cucu nabi Allah Sulaiman itu ke bawah angin seperti kebanyakan anak cucu orang Arab lepas ke bawah angin sampai meninggalkean anak cucu turun-temurun.

Berdasarkan kedua narasi ini sebenarnya terlihat bahwa Raja Ali Haji meragukan kehafsahan bahwa nenek moyang Orang Bugis yang berasal dari Nabi Sulaiman dan Ratu Balqis. Setidaknya terdapat beberapa alasan mengapa kemudian Raja Ali meragukan informasi tersebut. Pertama terkait geografis wilayah, sebagai seorang yang pernah mengunjungi Jazirah Arab ketika kecil, agaknya ia mengetahui dimana letaknya Negeri Yaman, sangat jauh dari tanah Bugis. Kedua, sebagaimana ditulisnya dalam SMB, sebelumnya ia belum pernah menemukan informasi tersebut dalam kitab tarekh (sejarah) yang pernah ia baca.

Sekalipun demikian, agaknya Raja Ali Haji belum berani memutuskan

35 Virginia Matheson Hooker, Tufhat AlNafis, Sejarah Melayu Islam., Ibid.

${ }^{36}$ Haji Abdullah, Silsilah Melayu Bugis, h. 9 apakah informasi tersebut dapat diverifikasi atau tidak. Di ujung tulisannya, baik pada TN maupun $\mathrm{SMB}$, ia mengembalikan hal tersebut kepada Allah Yang Maha Mengetahui. Oleh Hooker (1991), penulis disebut acuh untuk memberitahu yang sebenarnya. Ia dinilai lebih peduli pada narasi yang ingin disampaikan melainkan kebenaran informasi. ${ }^{37}$

Lebih lanjut, merujuk pada silsilah raja-raja Bugis tersebut, secara periodesasi, peristiwa yang ditulis terjadi sangat jauh dari zaman kehidupan Raja Ali Haji. Jaraknya bisa hingga ratusan tahun. Keterbatasan sumber pembanding, dan juga akses terhadap akses terhadap naskah-naskah tersebut membuat pengarang TN dan SMB tidak melakukan pengujian terhadap sumber yang akan digunakan. Dalam beberapa kajian yang berusaha melacak tahun atau masa hidup dari raja-raja Bugis tersebut, diketahui bahwa eksistensi raja-raja pada periode awal berada sejak abad ke-8 Masehi. ${ }^{38}$

Naskah TN lebih didominasi oleh kronologi sebagai haluan penulisan. Dalam hal ini penulis tidak menceritakan detil peristiwa pada suatu wilayah tertentu. ${ }^{39}$ Agaknya hal tersebut tidak hanya pada naskah $\mathrm{TN}$, dalam naskah SMB pun demikian. Penulis lebih fokus pada alur cerita, sehingga beberapa aspek yang menjadi poin utama dalam sejarah menjadi terabaikan, terutama terkait waktu atau

\footnotetext{
${ }^{37}$ Virginia Matheson Hooker, Tufhat AlNafis, Sejarah Melayu Islam., h. 70

38 Kerajaan Luwu merupakan salah satu kerajaan di Nusantara yang sudah eksis sejak lama. Kerajaan ini diperkirakan sudah eksis sejak abad ke-8 masehi, berangkat dari pemerintahan Batara Guru sebagai Datu Luwu I. Andi Ima Kesuma IC, Legacy Tana Luwu (Makasar: Dinas Kebudayaan dan Kepariwisataan Provinsi Sulawesi Selatan, 2015), h. 16

39 Virginia Matheson Hooker, Tufhat AlNafis, Sejarah Melayu Islam., h. 66
} 
periodesasi masa hidup tokoh pada silsilah yang ditulis. ${ }^{40}$

Corak penulisan sejarah yang dilakukan oleh Raja Ali Haji pada dasarnya tidak terlepas dari wawasan yang ia miliki. Selain memiliki karya di bidang sastra, bahasa dan sejarah, ia juga kerap berkorespodensi dengan orang asing. Pengetahuan di bidang agama dan kemampuan dalam menulis agaknya menjadi dasar baginya untuk mengembangkan wawasan untuk melahirkan sejumlah karya.

Salah satu orang asing yang tercatat pernah berkorespodensi dengan Raja Ali Haji adalah Herman Von de Wall yang datang ke Nusantara pada 1829. Selama di Nusantara ia tercatat pernah menjabat Asisten Residen di Borneo (Kalimantan). Setidaknya terdapat empat manuskrip berupa surat yang ditulis oleh Raja Ali Haji kepada Von de Wall. Dari empat buah surat tersebut, terdapat dua surat yang ditulis pada tahun 1870 yang di dalamnya Raja Ali Haji bercerita tentang aktivitas penulisan. Pada surat tertanggal 19 Mei 1870, Raja ia menceritakan progres penulisan yang dilakukan oleh Raja Ismail, hal lain yang dilakukannya kala itu adalah menyalin Sejarah Melayu. Pada tahun yang sama tanggal 1 September, ia juga menceritakan tentang progres penulisan kamus Melayu. ${ }^{41}$

Sekalipun cerita tentang aktifitas kepenulisan diceritakan pada tahun 1870, dan terjadi beberapa tahun

${ }^{40}$ Kajian sejarah terikat oleh waktu, berbeda dengan penelitian cabang keilmuan lain yang bisa mengabaikan hal tersebut. Sejarah tidak hanya berbicara tentang manusia dan apa yang dilakukannya, lebih spesifik, dalam sejarah hal yang paling utama adalah perbuatan manusia itu terikat oleh waktu yang ada di masa lalu. Lihat Kuntowijoyo, Pengantar Ilmu Sejarah, h. 47

${ }^{41} \mathrm{Al}$ Azhar dan Jan Van Der Putten, Four Malay Letters from Raja Ali Haji to Von de Wall', Bijdgragen tot de Taal-, Land en Volkenkunde, 148. 3/4 (1992), h. 521-528 setelah naskah TN dan SMB selesai ditulis, akan tetapi tidak tertutup kemungkinan pada surat-surat sebelumnya mereka juga berbagi cerita tentang masalah penulisan naskah tersebut. Sebab, riwayat surat menyurat antara Raja Ali Haji dengan Von de Wall sudah dimulai sejak tahun 1958. Selain itu, berdasarkan surat-surat tersebut, mereka diperkirakan sudah dekat cukup lama.

Selain dengan Von de Wall, Raja Ali Haji juga berkirim surat dengan Roorda van Eysinga di Batavia. Sekitar bulan Februari 1946, dalam suratnya diceritakan bahwa ia menerima dua buah cetakan cerita Melayu (Taj alSalatin dan Hikayat Sri Rama). Empat bulan setelahnya, pada surat yang lain ia mengirimkan surat beserta manuskrip Syair Sultan Abdul Muluk ke Batavia, dengan harapan Roorda van Eysinga dapat mencetak naskah tersebut. ${ }^{42}$

Sebenarnya tidak ada jaminan bahwasanya hal ini berpengaruh langsung terhadap aktifitas penulisan TN dan SMB yang dilakukan Raja Ali Haji. Akan tetapi hal ini juga tidak bisa diabaikan. Selain karena fakta bahwa ia adalah seorang yang gemar menulis dan sering berkorespodensi dengan orang asing, di dalam surat-suratnya Raja Ali Haji juga kerap bercerita tentang aktifitas penulisan yang sedang ia lakukan ataupun yang sedang terjadi di sekitarnya.

Hooker (1991) menyebut Raja Ali telah menulis sebuah karya sejarah yang dipengaruhi oleh nilai dan prinsip penulisan sejarah Islam klasik. ${ }^{43}$ Dalam periode perkembangan sejarah Islam, pada periode klasik penulisan nasab ataupun silsilah sudah mulai dilakukan. Cikal bakal hal tersebut bahkan sudah

${ }^{42}$ Jan Van Deer Putten, Printing in Riau: Two Steps Toward Modernity', Bijdgragen tot de Taal-, Land en Volkenkunde, 153. 4 (1997), h. 717-736.

${ }^{43}$ Virginia Matheson Hooker, Tufbat Al-Nafis, Sejarah Melayu Islam., h. 88 
ada sejak zaman jahiliyah. ${ }^{44}$ Pada naskah TN dan SMB, penulisan nasab kembali dilakukan oleh Raja Ali Haji terhadap riwayat atau silsilah raja-raja Bugis.

Secara umum, TN dan SMB adalah sebuah karya yang mulai keluar dari pola historiografi Islam awal di Indonesia. Pada periode ini, karya historiografi yang berkembang adalah karya sastra klasik yang di dalamnya terdapat bikayat, tambo, haba maupun kisah. ${ }^{45}$ Sekalipun belum mengarah pada sejarah kritis atau pun modern yang identik dengan analisis dari sebuah peristiwa, akan tetapi terdapat beberapa indikasi bahwa Raja Ali Haji tidak lagi menelan bulat-bulat narasi-narasi yang jauh dari fakta. Beberapa bagian bahkan sudah mulai dikritisi.

Secara spesifik, pada bagian penulisan silsilah, tidak ditemukan upaya lebih oleh Raja Ali Haji untuk mengkonfirmasi nama-nama yang terdapat dalam silsilah. Beberapa sumber yang ia rujuk masih karya-karya yang lahir di kawasan Melayu. ${ }^{46}$ Sementara pada kurun waktu abad ke19, sejumlah naskah yang berisi hal tersebut sudah ditulis di Negeri Luwuk. $^{47}$

44 Ajid Thohir, 'Historiografi Ketokohan dalam Penguatan Madzhab Fiqh dan Tasawuf, dalam Hitoriografi dan Sejarab Islam Indonesia (Bandung: LP2M UIN Sunan Gunung Djati, 2018), h. 41

45 Franz Rosenthal, A History of Muslim (Leiden: E.J. Brill, 1968), h. 8.

${ }^{46}$ Beberapa naskah lain yang disebut-sebut oleh Raja Ali Haji dalam TN di antaranya adalah Siarah Siak, Siarah Selangor, Siarah Pontianak, Hikayat Negeri Johor, Siarah Pihak Riau Karangan Engku Busu. Sementara untuk naskah SMB di dalamnya disebut-sebut naskah Siarah Pontianak. Selain itu, narasi dalam SMB juga mengutip dari Naskah Hikayat Opu Daeng Manambun. Virginia Matheson, 'The Tubfat Al-Nafis: Structure and Sources', Bijdgragen tot de Taal-, Land en Volkenkunde, 127. 3 (1971), h. 357-392.

${ }^{47}$ Di Sulawesi Selatan atau Negeri Bugis, sejak lama juga sudah ditulis sejumlah naskahnaskah yang di dalamnya memuat informasi tentang silsilah. Di antaranya terdapat Lontarak La
Walaupun demikian, sebagaimana dijelaskan di awal, Raja Ali Haji sudah meragukan narasi bahwasanya nenek moyang orang Bugis yang berasal dari Nabi Sulaiman dan Ratu Balqis. Sayangnya, di penghujung bagian tersebut, ia tidak memutuskan untuk membantah informasi itu, dan hanya menyebutkan hal tersebut hanya Allah yang tahu. Sementara dalam konsep metode penulisan sejarah, kritik internal terhadap sumber, seorang penulis harus menguji apakah informasi yang ada itu masuk akal, valid, layak atau tidak.

\section{KESIMPULAN}

Tuhfat Al-Nafis dan Silsilah Melayu Bugis adalah dua naskah yang ditulis oleh Raja Ali Haji pada waktu yang hampir bersamaan di pertengahan abad ke-19. Kedua naskah tersebut sama-sama memuat informasi tentang silsilah nenek moyang Upu Daeng Lima Bersaudara yang di kemudian hari anak cucunya menjadi sosok berpengaruh di Kawasan Melayu. Hanya saja, nama nenak moyang Upu Daeng Lima Bersaudara pada kedua naskah itu tidaklah sama. Jumlah yang ada pada Tuhfat Al-Nafis lebih sedikit dari naskah silsilah Melayu Bugis.

Karya-karya yang dilahirkan oleh Raja Ali haji tersebut dapat dikatakan sebagai karya sejarah pada periode transisi. Maksudnya peralihan dari sejarah klasik menuju sejarah modern di abad ke-20. Hal ini berangkat dari penerapan beberapa metode penelitian dan penulisan yang yang mulai digunakan oleh Raja Ali Haji, Sekalipun belum menggunakannya secara konsisten dan kritis, setidaknya hal itu sudah mulai digunakan oleh Raja Ali Haji.[]

\section{DAFTAR PUSTAKA}

Abdullah, Haji, Silsilah Melayu Bugis, terj. Evawarni dan Sindu Galba,

Galigo Lontarak Luwu. Ahmad Yunus, et.al, Lontarak Luwu Daerah Sulawesi Selatan (Jakarta: Departemen Pendidikan dan Kebudayaan, 1992), h.7-9. 
(Tanjungpinang: Balai Kajian Sejarah dan Nilai Tradisional, 1993).

Al Azhar dan Jan Van Der Putten, 'Four Malay Letters from Raja Ali Haji to Von de Wall', Bijdgragen tot de Taal-, Land en Volkenkunde, 148. 3de/4de (1992).http://www.jstor.org/stable/ 27864395

Becker, Carl. 'What is Historiography?', American Historical Review, 44. 1 (1938), https://doi.org/10.2307/1840848

Breisach, Ennst. Historiography: Ancient, Medieval and Modern (Chicago: The University of Chicago Press, 1994)

Dahlan, Ahmad, Sejarah Melayu (Jakarta: Kepustakaan Populer Gramedia, 2014).

Fang, Liaw Yock, Sejarah Kesusasteraan melayu Klasike (Singapura: Pustaka Nasional, 1982).

Hakim, Lukmanul, 'Historiografi Modern Indonesia: Dari Sejarah Lama Menuju Sejarah Baru', Khazanah: Jurnal Sejarah dan Kebudayaan Islam, 8. 16

(2018).

https://doi.org/10.15548/khazanah . $\mathrm{v} 0 \mathrm{iO} 0.75$

Hamid, Abd Rahman dan Muhammad Saleh Madjid, Pengantar Ilmu Sejarah (Yogyakarta: Ombak, 2015)

Hasan, Alimuddin, 'Historiografi Melayu: Kajian Atas Tuhfat al-Nafs Karya Raja Ali Haji', Al-Fikra: Jurnal Ilmiah Keislaman, 8. 2 (2009). DOI: 10.24014/af.v8i2.3818

Hooker, Virginia Matheson, Tufhat AlNafis, Sejarah Melayu Islam, trans. by Ahmad Fauzi Basri (Kuala Lumpur: Dewan Bahasa dan Pustaka Kementrian Pendidikan Malaysia, 1991).

Kesuma IC, Andi Ima, Legacy Tana Lumu (Makasar: Dinas Kebudayaan dan Kepariwisataan Provinsi Sulawesi Selatan, 2015).

Kuntowijoyo, Pengantar Ilmu Sejarah (Yogyakarta: Tiara Wacana, 2013).
Matheson, Virginia, The Tuhfat Al-Nafis: Structure and Sources', Bijdgragen tot de Taal-, Land en Volkenkunde, 127. 3 (1971).http://www.jstor.org/stable/ 27861195.

Mu’jizah, Historiografi Tradisional Rajaraja Melayu dan Kekuasaan dalam Hikayat Negeri Johor', Atavisme, 21. 1

(2018).10.24257/atavisme.v21i1.441. 17-34

Noorduyn, J, 'The Bugis Genealogy of the Raja Muda Family of RiauJohor', Journal of the Malaysian Branch of the Royal Asiatic Society, 61. 2 (1988).

http://www.jstor.org/stable/41493 $\underline{103}$

Overbeck, Hans, 'Silsilah Melayu Bugis dan Raja-rajanya', Journal of the Malayan Branch of the Royal Asiatic Society, $\quad 4 . \quad 3$ (1926).http://www.jstor.org/stable/ 41559676

Paranoto, Suhartono W, Teori \& Metodologi Sejarah (Yogyakarta: Graha Ilmu, 2014).

Putten, Jan Van Deer, 'Printing in Riau: Two Steps Toward Modernity', Bijdgragen tot de Taal-, Land en Volkenkunde, 153. 4 (1997). http://www.jstor.org/stable/27865 $\underline{396}$

Rahmat, Syahrul, 'Bugis di Kerajaan Melayu: Eksistensi Orang Bugis dalam Pemerintahan Kerajaan Johor-Pahang-Riau-Lingga', Perada, 2.1

(2019).https://doi.org/10.35961/pe rada.v2i1.25

Rosenthal, Franz, A History of Muslim (Leiden: E.J. Brill, 1968).

Sofyan, Faisal, Sejarah Persemendaan Melayu dan Bugis (Tanjung Pinang: Milaz Grafika, 2013).

Teng, Muhammad Bahar Akkase, "Tuhfat Al -Nafis: Karya Sastra Sejarah 
(Melayu) Dalam Perspektif Sejarah', Paramasastra, 2.1 (2015).

Thohir, Ajid, 'Historiografi Ketokohan dalam Penguatan Madzhab Fiqh dan Tasawuf, dalam Hitoriografi dan Sejarah Islam Indonesia (Bandung: LP2M UIN Sunan Gunung Djati, 2018).

Yunus, Ahmad, et.al, Lontarak Luwn Daerah Sulawesi Selatan Jakarta: Departemen Pendidikan dan Kebudayaan, 1992).

Zed, Mestika, Pengantar Studi Historiografi, (Padang: Universitas Andalas, 1984) 
Tabel 1

Silsilah Upu Daeng Lima Bersaudara berdasarkan Tuhfat Al Nafis dan Silsilah Melayu Bugis

\begin{tabular}{|c|c|c|c|}
\hline No & Tuhfat Al Nafis & No & Silsilah Melayu Bugis \\
\hline 1 & Sitti Mallangkik & 1 & Sitti Malangkayak \\
\hline 2 & Datuk Palingik & 2 & Datu Pelini \\
\hline 3 & Patotok & 3 & Patutuk \\
\hline 4 & Batara Guru & 4 & Tibara Guru \\
\hline 5 & Batara Lattuk & 5 & Batara Latuk \\
\hline 6 & Paduka Sawerigading & 6 & Sawara Kading \\
\hline 7 & La Galigo & 7 & Lakaliku \\
\hline 8 & Paduka Saung ri Warak & 8 & Tatak \\
\hline 9 & Lassalaka/Lattalaka & 9 & Sawang Ruwarak Latalaka \\
\hline 10 & Sialliajangnge Kurinna & 10 & Siyajangi Kurana \\
\hline 11 & Batari Toja Mallajangnge ri Lopi-bali & 11 & Batari Tuja Malajangi Lupi Bali \\
\hline 12 & To Tendrialak Mallajangnge ri Ulerenna & 12 & Tutandri Alak Maljangi Ularna \\
\hline 13 & La Rumapak Matindro ri Warak & 13 & Larmapak mutandru Ruwarak \\
\hline 14 & $\begin{array}{l}\text { La Sessung Riwuk Matindro ri } \\
\text { Larompong }\end{array}$ & 14 & Lassasung Ruwak Mutandru Ralarapung \\
\hline 15 & Tungkak Matindro ri Mallangkik & 15 & Batara Tungkah Mutandaruri Malangkayak \\
\hline \multirow[t]{2}{*}{16} & \multirow[t]{2}{*}{ La Pannyiwi Mallopi ri Alak } & 16 & Lupah Bayu Malupi Riyalaah \\
\hline & & 17 & Lupah Dulang Maljangi Rurallangi \\
\hline 17 & Sessung Riwuk Nannuk ri Peretiwi & 18 & Sasung Ruwak Nanuk Raqiri Tiwi \\
\hline 18 & To Akkasauk Matindro ri Usuk & 19 & Tukawasuk Mutandru Riyusuk \\
\hline 19 & Batara Tungkak Matindro ri Mallangkik & 20 & Batara Tungkak Mutandaruri Malangkayak \\
\hline \multirow[t]{2}{*}{20} & \multirow{2}{*}{$\begin{array}{l}\text { La Sessung Riwuk Matindro ri } \\
\text { Larompong }\end{array}$} & 21 & Sasung Ruwak Mutandaru Larapung \\
\hline & & 22 & Tuka Madang Mutandaru Ranpa \\
\hline 21 & To Allaik Matindro ri Tanatekko & 23 & Tulayak Mutandru Rotan Tuku \\
\hline 22 & Seri ri Warak Matindro ri Cabettikkak & 24 & Siti Rawarak Mutandru Rajab Tukak \\
\hline 23 & $\begin{array}{l}\text { La Wewang Langik Matindro ri } \\
\text { Langkanana }\end{array}$ & 25 & Lawung Langiyak Mutandaruri Langkanan \\
\hline 24 & $\begin{array}{l}\text { Makkarumapak Matindro ri } \\
\text { Tompoktikkak }\end{array}$ & 26 & Maakramapak Mutandru Ratampatakak \\
\hline 25 & La Mappepulung Luppak ri Mata-bessi & 27 & Lamapi Pulang Lapak Ramat Basi \\
\hline 26 & To Temmuik ri Pasitunu Sulocakna & 28 & Tutumuyak Rapisi Tunu Sulu Cikna \\
\hline 27 & $\begin{array}{l}\text { To Riabusungengnge Siallajangnge } \\
\text { Langkanana }\end{array}$ & 29 & Puriyak Basungpi Silajangi Ralangkanang \\
\hline 28 & Tendriliwang Matindro ri Larukodona & 30 & Tundari Layung Mutandaru Ralukudun \\
\hline 29 & $\begin{array}{l}\text { Tendro ri Balusue Mallajangnge ri } \\
\text { Kalakkakna }\end{array}$ & 31 & Tundari Ampak Mutandari Rabalusuya \\
\hline 30 & Kurilangi Matindro ri Cendrana & 32 & Kuri Langiyak Mutandaru Rancindaran \\
\hline 31 & La Tendriampak & 33 & Latundari Ampak \\
\hline \multirow[t]{2}{*}{32} & \multirow[t]{2}{*}{ Mappaseking Matindro ri Kannana } & 34 & Mapasilang Mutandaru Rasalakun \\
\hline & & 35 & Latuwandak Mutandaru Raknan \\
\hline 33 & La Tendriupak & 36 & Latundari Jupa \\
\hline
\end{tabular}




\begin{tabular}{|l|l|c|l|}
\hline 34 & Randreng ri Taluk Tendreng & 37 & Landung Tuluk Tundarin \\
\hline 35 & La Maddusila & 38 & La Madu sholat \\
\hline 36 & Daeng Rilakka & 39 & Daeng Rilakka \\
\hline 37 & Upu Daeng Lima Bersaudara & 40 & Upu Daeng Lima Bersaudara \\
\hline
\end{tabular}

96 Perada: Jurnal Studi Islam Kawasan Melayu, Vol. 4, No. 2, Desember 2021 